\title{
Calciphila, a New Genus in African Asclepiadeae (Apocynaceae, Asclepiadoideae), and Taxonomic Rectifications in Cynanchum
}

\author{
Sigrid Liede-Schumann and Ulich Meve \\ Department of Plant Systematics, University of Bayreuth, 95444 Bayreuth, Germany. \\ sigrid.liede@uni-bayreuth.de; ulrich.meve@uni-bayreuth.de
}

Aвstract. During work for the Flora of Somalia account of Apocynaceae subfamily Asclepiadoideae, a new species of uncertain affinity was discovered. DNA analysis revealed that the new species, Calciphila gillettii Liede \& Meve, is most closely related to the recently described Cynanchum galgalense Liede. which was only provisionally included in Cynanchum L. after DNA analysis. As the best taxonomic solution for the two species not fitting into any of the known genera of milkweeds, the description of a new genus. Calciphila Liede \& Meve, is proposed. Also, in the course of work for the Flora of Somalia, it was realized that Cynanchum clavidens N. E. Brown needs to be renamed Cynanchum hastifolium K. Schumann if the two taxa are considered to constitute subspecies of the same species, because $C$. clavidens has previously been put into synonymy with C. hastifolium. Finally. work on the Flore des Seychelles brought to light that Cynanchum robertsoniae Liede is identical with the Indian C. callialatum Buchanan-Hamilton ex Wight. and needs to be placed in synonymy with the latter. A lectotype is designated for C. callialatum.

Key words: Africa, Asclepiadeae, Calciphila. Cynanchinae, Cynanchum, Seychelles, Somalia.

During work on the Flora of Somalia treatment of Apocynaceae subfamily Asclepiadoideae, a specimen from the Botanical Museum of Uppsala Universits (UPS) could not be placed into any of the milkweed laxa known from there. While the small, leafless shrublet itself was sterile, a photograph clearly showing a Cynanchum viminale L. flower was attached, suggesting that the specimen constitutes a new taxon in the variable $C$. viminale group. However, closer examination revealed that the photograph could not have been taken from the plant on the specimen, because the size of the succulent shoot and its coloration did not match between specimen and picture. The plant itself was described on the label (Thulin et al. 10122, UPS) as having clear latex, a character so far unknown for the $C$. viminale group. On a second specimen obtained from the Kew Herbarium (K), luckily a few flowers were found. Size and structure of the extremely small flowers, logether with the clear latex, led to the inference that the plant might be possibly related to the Blyttia ArnottDiplostigma K. Schumann-Goydera Liede complex in the Tylophorinae, whose members possess clear latex and very small flowers with a variable corona, and are well known from Somalia. We then obtained permission to sequence DNA from the UPS specimen in order to clarify the position of the laxon. It soon became clear that the plant is the closest known relative to Cynanchum galgalense Liede, which had been left in Cynanchum L. for its corona morphology even though molecular results did not support that position (Liede \& Kunze, 2002); indeed the position of the two species in the Asclepiadeae is still puzzling.

\section{Mathial and Methods}

From the specimen Thulin et al. 10122 (UPS), we managed to obtain DNA sequences of the regions commonly used in our lab for phylogenetic reconstructions, namely, ITS (nrDNA) and the $\operatorname{trn}$ T-L, $\operatorname{trnL}$ F spacer and the $1 r n \mathrm{~L}$ intron (cpDNA). In order to learn about the position of the specimen, two routes were followed. First, the sequences were inserted in recently published alignments of Asclepiadoideae (Astephaninae, Liede, 2001: Cynanchum. Liede \& Täuber, 2002: African Cynanchum, Liede \& Kunze. 2002; Tylophorinae, Liede et al., 2002). The datasets are available from the authors upon request. Second, a basic local alignment search tool (BLAST) search (Alishul et al., 1997) was conducted for each of the four partial sequences (Table 1).

\section{RESITS}

The results of both approaches (cf. Material and Methods) show clearly that not only the morphological characters of the new species, but also its DNA characters constitute a mosaic between various taxa known from the area (Table 1). While there is little doubt that the closest relative to the new species is Cynanchum galgalense, another endemic from calcareous regions in Somalia, the position of the two species is less clear. Depending on the dataset, the two species are placed (1) on a polylomy comprising 
Table 1. Results of the BLAST analysis of the four partial sequences of Calciphila gillettii.

\begin{tabular}{|c|c|c|c|c|}
\hline & $\begin{array}{l}\text { Name of the taxon } \\
\text { with the most similar } \\
\text { sequence (voucher) }\end{array}$ & $\begin{array}{l}\text { Accession } \\
\text { number of the } \\
\text { most similar } \\
\text { sequence }\end{array}$ & $\begin{array}{l}\text { Score (bits)/ } \\
\% \text { identity }\end{array}$ & Notes \\
\hline ITS & $\begin{array}{l}\text { Cynanchum ellipticum } \\
\text { (Harvey) R. A. Dyer } \\
\text { (Liede 2933, UBT) }\end{array}$ & AJ 320444 & $646 / 94 \%$ & $\begin{array}{l}\text { Positions 2-4 taken by other African } \\
\text { Cynanchum species (score } 638 \text { bits/94\% } \\
\text { identity), C. galgalense (Thulin \& Warfa 6205) } \\
\text { only on position } 5 \text { (630/94\%), again followed } \\
\text { by two African Cynanchum species ( } 624 \& \\
622 \text {, respectively/93\%) and Schizostephanus } \\
\text { alatus }(615 / 93 \%) \text {. }\end{array}$ \\
\hline $\begin{array}{l}\text { trnT-L } \\
\text { intergenic } \\
\text { spacer }\end{array}$ & $\begin{array}{l}\text { C. galgalense (Thulin, } \\
\text { Dahir \& Osman } 9433 \text {, } \\
\text { UPS) }\end{array}$ & AJ492340 & $511 / 73 \%$ & $\begin{array}{l}\text { Positions } 2-21(504-490 / 73 \%-72 \%) \text { taken by } \\
\text { Tylophorinae (e.g., Tylophora heterophylla } \\
\text { A. Richard); the second specimen of } \\
\text { C. galgalense (Thulin \& Warfa } 6205 \text {, K, UPS) } \\
\text { ranges } 22 \text { nd }(490 / 72 \%) \text {. }\end{array}$ \\
\hline$t r n \mathrm{~L}$ intron & $\begin{array}{l}\text { C. galgalense (Thulin, } \\
\text { Dahir \& Osman 9433, } \\
\text { UPS) }\end{array}$ & AJ492340 & $969 / 98 \%$ & $\begin{array}{l}\text { Position } 2 \text { taken by the } 2 \text { nd specimen of } \\
\text { C. galgalense (Thulin \& Warfa 6205, UPS) } \\
\text { (954/98\%), followed by several } \\
\text { Metastelmatinae (e.g., Metastelma schaffneri A. } \\
\text { Gray) and Tylophorinae (e.g., Tylophora tenuis } \\
\text { Blume) species (906-888/96\%). }\end{array}$ \\
\hline $\begin{array}{l}t r n \mathrm{~L}-\mathrm{F} \\
\text { intergenic } \\
\text { spacer }\end{array}$ & $\begin{array}{l}\text { C. galgalense (Thulin, } \\
\text { Dahir \& Osman 9433, } \\
\text { UPS) }\end{array}$ & A.J492342 & $692 / 98 \%$ & $\begin{array}{l}\text { Position } 2 \text { taken by the } 2 \text { nd specimen } \\
\text { C. galgalense (Thulin \& Warfa 6205, UPS; } \\
658 / 96 \%) \text {, followed by Schizostephanus alatus } \\
(646 / 96 \%) \text {, and } 16 \text { Madagascan Cynanchum } \\
\text { spp. }(642 / 98 \%) \text {. }\end{array}$ \\
\hline
\end{tabular}

Oxystelma R. Brown (occurring together with Solenostemma Hayne), Tylophorinae, and Asclepiadinae (cpDNA datasets; Liede, 2001; Liede \& Täuber, 2002), (2) in an association with Schizostephanus Hochstetter ex K. Schumann (Cynanchinae; cpDNA dataset combined with ITS; Liede \& Kunze, 2002), or (3) in a sister-group position to the Tylophorinae (cpDNA dataset combined with ITS; Liede et al.. 2002). As ITS sequences between Cynanchinae, Tylophorinae, and Asclepiadinae are so different that unambiguous alignments are impossible, no ITS alignment comprising members of all subtribes has been created.

Taking the isolated position of the new taxon and the character mosaic of the two sister species into account, it is considered taxonomically practical to distinguish the two species from Cynanchum L. as the new genus Calciphila Liede \& Meve.

Calciphila Liede \& Meve, gen. nov. TYPE: Calciphila galgalensis (Liede) Liede \& Meve.

Plantae foliis carnosulis inferioribus caducis; latice pellucido; coronis gynostegialibus cyathiformibus vel urceolatis, partibus staminalibus interstaminalibusque late connatis, sulcatis; gynostegiis pyramidalibus; seminibus tuberculatis.

Pubescent, twiners or shrublets with small, fleshy caducous leaves; latex clear. Flowers very small, to
$1.5 \times 1 \mathrm{~mm}$, rotate with corolla lobes \pm erect to produce a cyathiform structure; gynostegial corona urceolate to cyathiform, consisting of staminal and interstaminal parts fused for at least $3 / 4$ of total corona length, sulcate, emarginate; gynostegium pyramidal with oblique guide rails along the whole length of anthers, connective appendages triangular; pollinia pendulous, oblongoid; style head umbonate to tabular. Follicles thin-walled, fusiform; seeds tuberculate.

Distribution. Two species endemic to Somalia.

The new genus exhibits a unique mosaic of characters. Some characters, in particular a highly fused corona overtopping the gynostegium and the corolla lobes either glabrous or equally covered with verrucose trichomes, are also typical of Cynanchum. Other characters, in particular the clear latex and the fleshy caducous leaves, are very similar to some Tylophorinae genera, in particular Goydera, Blyttia, and Diplostigma. Ecologically, the new genus is characterized by its preference for calcareous soils, to which the genus name refers. All plants recorded to date were found only on limestone.

\section{Key to the Species of Calciphila in Somalia}

la. Erect shrublet with leaves to $2 \mathrm{~mm}$ long, shoots green; corolla purplish cream, glabrous; gynostegium stipitate, corona cyathiform. . . . . . . . $\ldots \ldots \ldots \ldots \ldots$ gillettii, new species 


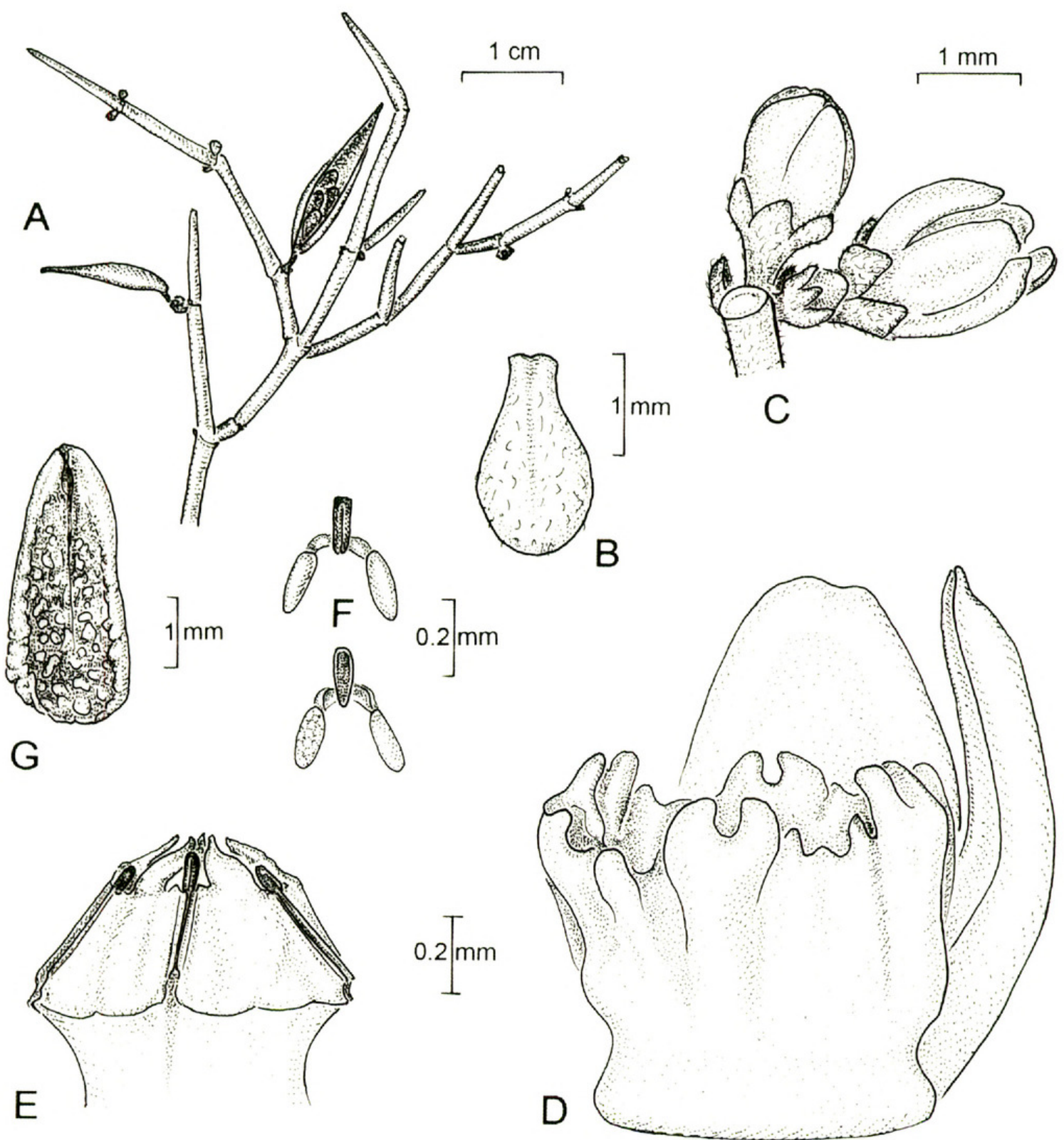

Figure 1. Calciphila gillettii Liede \& Meve. - N. Fruiting branch. - B. Leaf. - C. Inflorescence. - D). Flower (corona in lateral view, calyx and parts of the corolla removed). - E. Cynostegium. - F. Pollinarium (top: frontal view: bottom: back view). - G. Seed (sela side). A \& G from Thulin el al. 10122 (UPS): B-F from Gillell \& Watson 2.380.5 (K). All drawn bv U. Meve.

1b. Climber with leaves $1-14 \mathrm{~mm}$ long, shoots vellowish to brownish: corolla ream-colored. with verrucose trichomes; gynostegium sessile, corona

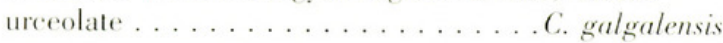

1. Calciphila gillettii Liede \& Meve, sp. nov. TYPE: Somalia. Bari: rocky hill, 7 July 1981. J. B. Gillett \& R. U. Watson 23805 (holotype, K). Figure 1.

Fruticuli nani, ramosissimi: caulibus virgatis. non volubilibus; foliis obovatis, succulentis, $1.5-2 \mathrm{~mm}$ longis, mox siccesscentibus; corollis purpureis, glabris: coronis gynostegialibus cyathiformibus: gynostegiis stipitatis. Differt a $\mathrm{Cr}_{\text {- }}$ nancho speciebus caulibus viridibus, latice hvalino, a Tylophorinarum speciebus coronis late connatis.
Erect virgate shrublets, $5-40 \mathrm{~cm}$ high, richly branched: shoots perennial, woody to herbaceous, green, densely covered with recurved trichomes, $80 \mu \mathrm{m}$ long: internodes $1-2.5 \times 0.15-0.3 \mathrm{~cm}$ : latex colorless: stipule-like short shoots absent. Leaves caducous, absent at the time of flowering, sessile, blades fleshy, $1.5-2 \times 1 \mathrm{~mm}$, obovate. apically obtuse, marginally straight and thickened, adaxially and abaxially sparsely pubescent with recurved trichomes, $50-100 \mu \mathrm{m}$ long: colleters absent. Inflorescences always one per node, extra-axillary, 3to 10-flowered. 2 to 5 flowers open synchronously, sciadioidal, sessile: floral bracts $0.5 \times 0.3 \mathrm{~mm}$. deltoid, with abaxial trichomes; pedicels $0.5 \mathrm{~mm}$ long. 
densely pubescent with recurved trichomes, $100 \mu \mathrm{m}$ long. Floral buds $1.5 \times 1 \mathrm{~mm}$, globose to ovoid, with imbricate aestivation, dextrorse; calyx basally fused; with abaxial trichomes, lobes $0.4 \times 0.3 \mathrm{~mm}$, triangular-deltate; corolla $1.5 \mathrm{~mm}$ long, abaxially cream, adaxially purple, lobes basally fused, 0.7$0.8 \mathrm{~mm}$ wide, ascending to erect, oblong, apically obtuse; gynostegial corona cyathiform, white, glabrous, ca. 0.9-1 mm long, consisting of connate staminal and interstaminal parts, exceeding the gynostegium and partly obscuring it; tube reaching more than $3 / 4$ of corona length, with a slight basal constriction; staminal parts producing a pronounced convex fold along the upper half of corona, slightly cucullate, apically bifid with rounded apices, longer than the rectangular, \pm erect, emarginate interstaminal parts; gynostegium $0.9 \times 1 \mathrm{~mm}$, atop a stipe of $0.3 \mathrm{~mm}$; anthers broader than long, trapezoidal. abaxially convex; anther wings $350 \mu \mathrm{m}$ long, extending along whole length of anther, consisting of distal and proximal ridge; anther wings of adjacent anthers parallel to each other, in the same plane as the anther: connective appendages $150 \times 120 \mu \mathrm{m}$ wide, triangular, narrower than the stamen, strongly inflexed. Pollinarium: corpusculum $100 \mu \mathrm{m}$ long, more than twice as long as broad, elliptic, margins of the corpuscular cleft parallel; caudicles $50 \mu \mathrm{m}$ long, (sub-)basally inserted at the corpusculum, flattened, convexly recurved, rectangular; pollinia apically attached to the caudicles, 160-180 $\times 60 \mu \mathrm{m}$ wide, elliptical in cross section, oblongoid; style-head white, $0.4 \times 0.5 \mathrm{~mm}$, upper part $0.1 \mathrm{~mm}$ high, shorter than the lower part, tabular. Follicles 1 per flower, erect to horizontal, 13-18 × $2.5 \mathrm{~mm}$ diam., fusiform, terete, apically short-beaked, greenish light brown, uniformly colored, smooth, with dense indumentum, with papery pericarp; seeds ca. 4 to 8 per follicle, ca. $4 \times$ $1.8 \mathrm{~mm}$, oblong, dark brown, tuberculate, papillose, marginally with $0.3 \mathrm{~mm}$ wing, multicellular in cross section, with enrolled margin; coma ca. $6 \mathrm{~mm}$ long, pure white.

Phenology. Flowering in July. Fruiting in January.

Distribution and habitat. Flat areas of limestone slopes, from 1300 and $1600 \mathrm{~m}$, in Somalia. Often growing under larger shrubs; heavily grazed by goats.

Conservation status. Very localized, but common in its area (IUCN classification: EN Bla).

The insignificant habit of the new species, notable for its small, caducous leaves and tiny flowers to less than $1 \mathrm{~mm}$ diam., explains its long absence from the literature. Furthermore, the casual observer might easily mistake Calciphila gillettii for some species of
Asparagus L., Euphorbia L., or Cynanchum (former Sarcostemma R. Brown), and the very localized distribution area adds further to its obscurity.

Paratype. SOMALIA. Bari: Al Miskat, N Dasan in Dal loád area, 1600 m, Thulin, Abdi Dahir \& Osman 10122 (K, UPS).

EMBL accession numbers of DNA sequences. ITS: AM229664; trnT-L intergenic spacer: AM229661; trnL intron: AM229662; trnL-F intergenic spacer: AM229663.

2. Calciphila galgalensis (Liede) Liede \& Meve, comb. nov. Basionym: Cynanchum galgalense Liede, Ann. Missouri Bot. Gard. 83: 312. 1996b. TYPE: Somalia. Bari: Al Miskat Mts., ca. 15 km SW of Candala, Toh well, 2 Dec 1985, Thulin 5612 (holotype, K; isotype, UPS).

\section{CinavChuM HaSTIFOLIUM}

Also in the course of the Asclepiadoideae treatment for Flora of Somalia, editor Mats Thulin (UPS) alerted us to the fact that Cufodontis (1960) gives a different nomenclatural history for the taxon described as Cynanchum clavidens N. E. Brown in Liede (1996b). Following the then most-recent edition of Index Kewensis, as well as Bullock's (1963) treatment of Asclepiadaceae for Flora of West Tropical Africa, Liede (1996b) attributed the name C. hastifolium-as well as C. clavidens-to N. E. Brown (1895). Cufodontis (1960), however, showed that C. hastifolium has to be attributed to $\mathrm{K}$. Schumann (1895), who based it on a nomen nudum, Cynoctonum hastifolium Hochstetter ex Schweinfurth (1867), because the publication of Schumann (1895) look place in May and the one of N. E. Brown (1895) in October. Luckily, Cufodontis (1960) selected the type indicated by N. E. Brown (1895), Schimper 1690, to lectotypify C. hastifolium K. Schumann; however, he did so without explicitly stating that he (Cufdodontis, 1960) was carrying out a lectotypification. Cufodontis (1960) also realized the conspecifity of Cynanchum hastifolium and C. clavidens N. E. Brown. Liede (1996b) came to the conclusion that C. clavidens and C. hastifolium deserve subspecific recognition, but unaware of the difference in time pointed out by Cufodontis (1960), she selected $C$. clavidens as name for the species, maintaining $C$. hastifolium at subspecific level as $C$. clavidens subsp. hastifolium (N. E. Brown) Liede. However, C. hastifolium K. Schumann has priority over $C$. hastifolium N. E. Brown and C. clavidens N. E. Brown, and therefore, C. hastifolium subsp. hastifolium has to be the typical subspecies, and the new combination $C$. hastifolium subsp. clavidens becomes necessary. 


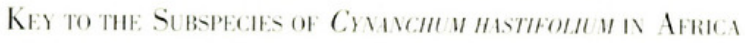

la. Style head well exceeding the corona, floral buds 6-6.5 mm long. . . . C. hastifolium subsp. claridens

1b. Style head not or hardly exceeding the corona: floral buds 3-1 mm long ... . . . . . . . . . .......... hastifolium subsp. hastifolium

1a. Cynanchum hastifolium subsp. hastifolium K. Schumann, in Engler \& Prantl, Nat. Pflanzenfam. 4(2): 253. 1895. Cynanchum hastifolium N. E. Brown, Bull. Misc. Inform. Kew 106: 257. 1895. Cynanchum clavidens subsp. hastifolium (N. E. Brown) Liede, Ann. Missouri Bol. Gard. 83: 306. 1996b. TYPE: Ethiopia. Prope Djeladjeranne, 29 Aug. 1840, W. G. Schimper 1690 (holotype, K; isotype, P).

The taxon has seen a number of invalid descriptions, all attributing the name to Hochstetler: Cynoctonum hastifolium Hochstetter ex Schweinfurth (1867: 128), nom. nud., Vincetoxicum hastifolium Hochstetter ex Oliver (1888: 320), nom. nud. The name Cynanchum hastifolium was also attributed to Hochstetter by Schumann (1895) as "C. hastifolium (Hochst.) K. Schum." Most likely, the taxon was intended for description by Hochstetter, as it can be deduced from the annotation of the type with a printed label, "Cynoctonum hastifolium Hochstetter," but the description was obviously never published.

1b. Cynanchum hastifolium subsp. clavidens (N. E. Brown) Liede, comb. el stat. nov. Basionym: Cynanchum clavidens N. E. Brown, Bull. Misc. Inform. Kew 106: 256. 1895; Cynanchum flavidens N. E. Brown, Index Kewensis Suppl. 1: 121. 1906, spelling error for Cynanchum clavidens. TYPE: Ethiopia. Ogaden: Boobi, 5 Feb. 1933, F. L. James \&. J. G. Thrupp s.n. (holotype, K).

\section{CrNanCHU CALIILATUM}

Lastly, in the course of studies for the Flore des Seychelles, Friedmann (1994) lists only one species of Cynanchum for the archipelago, a probably introduced Indian species, C. callialatum Buchanan-Hamilton ex Wight. Comparison of C. robertsoniae Liede, hitherto known only from the lype, with this material and with Indian material, quickly revealed that $C$. robertsoniae is not, as the author thought, a rare relative of African Cynanchum, but a synonym of C. callialatum, for which a lectotype needs to be selected.

1. Cynanchum callialatum Buchanan-Hamilton ex Wight, Contr. Bot. India 56. 1834. Cunoctonum callialatum (Buchanan-Hamilton ex Wight)
Decaisne. Prodr. 8: 528. 1844. Vincetoxicum callialatum (Buchanan-Hamilton ex Wight) Kuntze, Revis. Gen. Pl. 2: 424. 1891. Cyathella callialata (Buchanan-Hamilton ex Wight) C. Y. Wu \& D. Z. Li, Acta Phytotax. Sin. 28(6): 46.5. 1990. TY PE: India. N. Wallich, Herb. Asclep. $83 a$ (lectolype, designated here, K).

Cynanchum robertsoniae Liede, syn. nov. Kew Bull. 50: 805808. 1995. TYPE: Seychelles. Mahé. 13 Oct. 1936. C. Osborne-Day 201 (holotype, BM).

The transfer of a group of laxa, including Cynanchum calliatum, to Cyathella Decaisne by Li et al. (1990), mainly for phytochemical reasons, has found no support by later workers and is not followed here. While their (Li et al., 1990) decision to separate Vinceloxicum Wolf from Cynanchum is well documented by morphological, phytochemical, and molecular data (e.g., Liede, 1996a; Liede \& Täuber, 2002). the species of Cyathella in recent molecular analyses form a well-defined group within the larger Cynanchum clade and might deserve subgeneric or sectional stalus (Liede \& Täuber, 2002), but cannot be considered an independent genus.

Wight (1834: 56) lists three syntypes for Cynanchum callialatum, "Herb. Ham. ! n. 768; Wall. ! Ascl. n. 83; Wight.! cal. n. 1551." The first of these, Herb. Ham. 768, could not be traced, and its presumed existence in CAL could not be confirmed. The second one, Wall. Ascl. n. 83 is extant in the Wallich Herbarium of the Royal Botanic Gardens, Kew. It consists of Iwo sheets, with $83 a$ and 836 penciled on them. Number $83 a$ is the better of the two, with one flowering shoot and one fruiting one. The label has "Cynanchum callialata" and "Botanical Garden 8 Jamuary 1815" written in ink, and "ascl.83.a" written in pencil. As Wall. Ascl. n. 83 a represents an easily accessible, complete, and well-preserved specimen, it is selected as lectotype for $C$. callialatum here.

Actinouledgments. We thank Mats Thulin and David Goyder (K) for their help with specimen information. We thank the directors of $K$ and UPS for the loan of specimens, and the director of UPS for the permission to extract DNA from a specimen. We also thank Pat Matyot, Island Conservation Society, Seychelles, for alerting us to Friedman (1994).

\section{L.iterature Cited}

Altschul, S. F., T. L. Madden, A. A. Schäffer, J. Zhang, Z. Zhang. W. Miller \& D. J. Lipman. 1997. Gapped BLAST and PSI-BIAST: 1 new generation of protein database search programs. Nucl. Acids Res. 25: 3389-3402.

Brown. N. E. 1895. Diagnoses Africanae VIII. Bull. Misc. Inform. Kew 189.5: 217-26.5. 
Bullock, A. A. 1963. Asclepiadaceae. Pp. 85-103 in J. Hutchinson \& J. M. Dalziel (editors), Flora of West Tropical Africa, Vol. 2. Milbank, London.

Cufodontis, G. 1960. Asclepiadaceae. In Enumeratio Plantarum Aethiopiae Spermatophyla. Bull. Jard. Bot. État 30(Suppl.): 693-708.

Friedmann, F. 1994. Asclepiadaceae. Pp. 470-484 in Flore des Seychelles, Vol. Dicotylédones. Orstom, Paris.

Li, D.-Z., S.-X. Qiu \& C.-Y. Wu. 1990. The chemotaxonomy of Cynanchum and its allied genera. Acta Phytotax. Sin. 28: $461-466$.

Liede, S. 1996a. Cynanchum-Rhodostegiella-VincetoxicumTylophora: New considerations on an old problem. Taxon 45: 193-211.

1996b. A revision of Cynanchum (Asclepiadaceae) in Africa. Ann. Missouri Bot. Gard. 83: 283-345.

2001. Molecular considerations on the subtribe Astephaninae Endl. ex Meisn. (Apocynaceae-Asclepiadoideae). Ann. Missouri Bol. Gard. 88: 657-668.

\& H. Kunze. 1993. A descriptive system for corona analysis in Asclepiadaceae and Periplocaceae. Pl. Syst. Evol. 185: 275-284.
$\&$ 2002. Cynanchum and the Cynanchinae (Apocynaceae-Asclepiadoideae) -a molecular, anatomical and latex triterpenoid study. Organisms Diversity Evol. 2: 239-269.

\& A. Täuber. 2002. Circumscription of the genus Cynanchum (Apocynaceae-Asclepiadoideae). Syst. Bot. 27: 789-801.

- \& J. Schneidt. 2002. Molecula considerations on the Tylophorinae K. Schum. (Apocynaceae-Asclepiadoideae). Edinburgh J. Bot. 59: $377-403$.

Oliver, D. 1888. Flora of Somaliland. Pp. 317-323 in F. L. James (editor), The Unknown Horn of Africa: An Exploration from Berbera to the Leopard River. G. Philip, London.

Schumann, K. 1895. Asclepiadaceae. Pp. 189-305 in A. Engler \& K. Prantl (editors), Die Natürlichen Pflanzenfamilien, Vol. 4, 1. Engelmann, Leipzig.

Schweinfurth, G. 1867. Beitrag zur Flora Aethiopiens. Reimer, Berlin.

Wight, R. 1834. Contributions to the Botany of India. Parbury, Allen, London. 

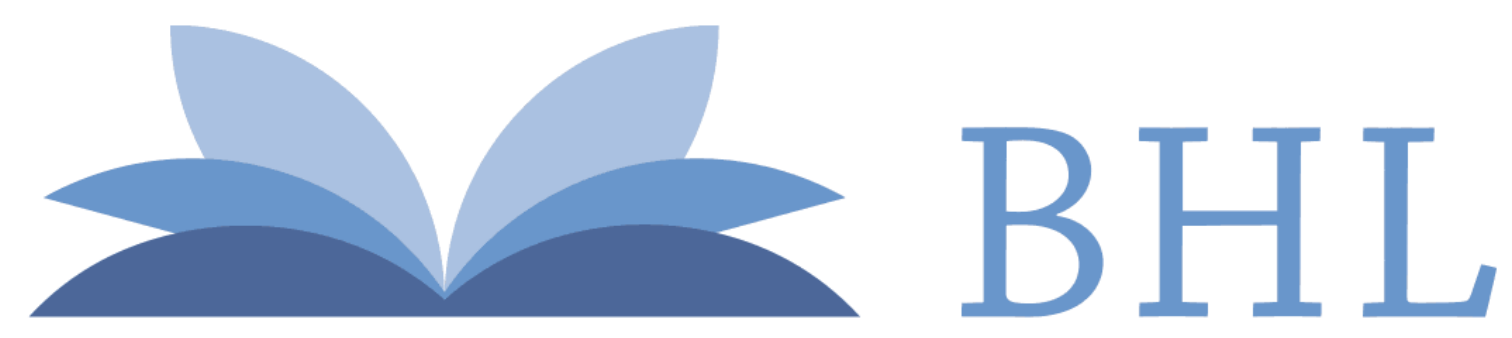

\section{Biodiversity Heritage Library}

Liede, Sigrid and Meve, Ulrich. 2006. "Calciphila, a New Genus in African Asclepiadeae (Apocynaceae, Asclepiadoideae), and Taxonomic Rectifications in Cynanchum." Novon a journal of botanical nomenclature from the Missouri Botanical Garden 16, 368-373.

View This Item Online: https://www.biodiversitylibrary.org/item/41804

Permalink: https://www.biodiversitylibrary.org/partpdf/121806

\section{Holding Institution}

Missouri Botanical Garden, Peter H. Raven Library

\section{Sponsored by}

Missouri Botanical Garden

\section{Copyright \& Reuse}

Copyright Status: In copyright. Digitized with the permission of the rights holder.

License: http://creativecommons.org/licenses/by-nc-sa/3.0/

Rights: https://biodiversitylibrary.org/permissions

This document was created from content at the Biodiversity Heritage Library, the world's largest open access digital library for biodiversity literature and archives. Visit BHL at https://www.biodiversitylibrary.org. 